\title{
Quantitation, Absorption and Tissue Distribution of Coenzyme Q10 from Pak-wanban (Sauropus androgynus L. Merr.) Leaf and Its Antioxidant Activities
}

\author{
Aikkarach KETTAWAN ${ }^{1}$ and Kansuda WUNJUNTUK ${ }^{2, *}$ \\ ${ }^{1}$ Division of Food Chemistry, Institute of Nutrition, Mahidol University, Nakhon Pathom 73170, Thailand \\ ${ }^{2}$ Department of Home Economics, Faculty of Agriculture, Kasetsart University, Bangkok 10900, Thailand
}

('Corresponding author's e-mail: fagrkdw@ku.ac.th)

Received: 18 April 2019, Revised: 17 September 2019, Accepted: 13 October 2019

\begin{abstract}
Pak-wanban (Sauropus androgynus L. Merr.), a popular Thai vegetable, has been found to have a high content of Coenzyme Q10 (CoQ10), which is a powerful antioxidant. This study investigated the quantitation, absorption and tissue distribution of CoQ10 from raw and stir-fried Pak-wanban and its antioxidant activities in rats. Male Wistar rats (seven weeks old) were randomly grouped as follows: (1) control, (2) raw Pak-wanban powder of $0.5 \mathrm{mg} \mathrm{CoQ10/kg/day,} \mathrm{(3)} \mathrm{stir-fried} \mathrm{Pak-wanban} \mathrm{powder} \mathrm{of} 0.5$ $\mathrm{mg} \mathrm{CoQ} 10 / \mathrm{kg} /$ day, (4) stir-fried Pak-wanban powder of $1.0 \mathrm{mg}$ CoQ10/kg/day, and (5) commercially CoQ10 supplement groups of $0.5 \mathrm{mg}$ CoQ10/kg/day. The results found that stir-fried cooking did not significantly reduce the content of CoQ10 in the Pak-wanban leaves. After 3 weeks of experimentation, the level of CoQ10 in the plasma, liver and spleen was increased in all Pak-wanban groups when compared to the control group. The level of CoQ10 in the stir-fried Pak-wanban group was significantly higher than the raw Pak-wanban group but slightly lower than the CoQ10 supplement group. Liver alpha-tocopherol concentrations were markedly increased in rats that consumed a high dose of CoQ10 from stir-fried Pak-wanban of $1 \mathrm{mg}$ of CoQ10/kg/day when compared with the control group. Plasma antioxidant activities (ORAC: FRAP: DPPH) were significantly increased in both groups of stir-fried Pak-wanban when compared with the control group. We concluded that CoQ10 in Pak-wanban could be well absorbed and improved the plasma antioxidant activities. Furthermore, cooking oil may increase the bioavailability of CoQ10 from vegetables. Therefore, it would be useful for vegetarian people.
\end{abstract}

Keywords: Pak-wanban, Sauropus androgynus L. Merr., Coenzyme Q10, Absorption, Antioxidant

\section{Introduction}

Coenzyme Q10 (CoQ10) or Ubiquinone10 (UQ10), an isoprenylated benzoquinone, is well-known for its role as an electron carrier in the mitochondrial electron transport chain (respiratory chain) for adenosine triphosphate (ATP) production. Furthermore, CoQ10 in its reduced form as a hydroquinone called ubiquinol is a potent lipophilic antioxidant and is capable of recycling and regenerating other antioxidants; such as tocopherol and ascorbate. A deficiency in CoQ10 has been associated with 5 different clinical presentations: (1) encephalomyopathy, (2) severe infantile multi-systemic disease, (3) cerebellar ataxia, (4) isolated myopathy and (5) nephrotic syndrome that suggest genetic heterogeneity, which may be related to the multiple steps in CoQ10 biosynthesis. Patients with all forms of CoQ10 deficiency have shown clinical improvements after initiating oral CoQ10 supplementation [1]. Dietary CoQ10 is primarily derived (64\% of the total) from meat and poultry [2,3]. Other sources of CoQ10 are 
http://wjst.wu.ac.th

soya oil, fish oils, peanuts, sardines, mackerel, herring and trout. The daily intake from food was estimated to be 2 - $5 \mathrm{mg}$ of CoQ10 a day, which has always been inadequate to provide the required levels beneficial to the body in pathological states [2,4]. Because of its hydrophobicity and large molecular weight, absorption of dietary CoQ10 from the small intestine passes into the lymphatic system, and finally into the blood and tissues, which is slow and limited. Supplementing CoQ10 in the diet does not increase the tissue levels above normal whereas intestinal absorption is threefold faster if CoQ10 is administrated with the intake of food [5]. Previous studies revealed that $30 \mathrm{mg}$ per day of CoQ10 consumption was generally recommended to maintain normal serum concentrations, and $30-300 \mathrm{mg}$ per day of CoQ10 consumption was recommended to prevent heart diseases [2,4,6].

Sauropus androgynus L. Merr., belonging to the family Euphorbiaceae, is one of the most popular indigenous plants in Southeast Asia. It is known as Star gooseberry, Sweet leaf bush, Cekur manis in Malaysia, Katuk in Indonesia, Binahian in Philippines, Dom nghob in Cambodia, and Pak-wanban in Thailand [7]. It is known as a "multigreen" vegetable due to its perceived superior nutrition and vitamin content in comparison to other vegetables [8]. The leaves of Sauropus androgynus L. Merr. or Pak-wanban have a high level of provitamin A carotenoids, especially in freshly picked leaves, as well as high levels of vitamin B and C, protein and minerals. Ethanolic extracts of Sauropus androgynus L. Merr. have shown anti-inflammatory effects on nitric oxide inhibitory activity and antioxidant activity [9]. Several studies reported positive antioxidant activity of Sauropus androgynus L. Merr. leaves [10 - 12]. Andarwulan et al. [10] found that Sauropus androgynus L. Merr. leaves had the highest flavonoid content among 11 vegetables of Indonesian origin. Additionally, Rahmat et al. [12] showed that the antioxidant activity of fresh and boiled shoot samples of Sauropus androgynus L. Merr. was higher than that of alpha-tocopherol. Moreover, previous studies reported that Sauropus androgynus L. Merr. had beneficial effects as a form of anti-obesity medication [13] and antimicrobial activity against Klebsiella pneumoniae and Staphylococcus aureus [14].

Furthermore, the present preliminary study analyzed the content of CoQ10 in Thai indigenous vegetables. The leaves of Pak-wanban or Sauropus androgynus L. Merr. were found to have approximately $5 \mathrm{mg}$ of CoQ10 per 100 grams of fresh leaves and $0.6 \mathrm{mg}$ of CoQ9 per 100 grams, thus having a CoQ10 content higher than other Thai indigenous vegetables, such as Chinese cabbage $0.3 \mathrm{mg}$, Eggplant $0.2 \mathrm{mg}$, and Parsley $2.6 \mathrm{mg}$ per 100 grams [15]. However, little is known about CoQ10 absorption and tissue distribution from the plant. Therefore, this study investigated the absorption and tissue distribution of CoQ10 from a popular Thai vegetable, Pak-wanban, and its antioxidant activities in a rat experiment model.

\section{Materials and methods}

\section{Chemicals and reagents}

All solvents were high performance liquid chromatography (HPLC) grade quality purchased from Wako Pure Chemical Industries, Ltd., Osaka, Japan. The Coenzyme Q10 standard was donated by Nisshin Pharma Inc., Tokyo, Japan. All the other reagents were an analytical grade from Sigma-Aldrich, St. Louis, MO, USA.

\section{Animals}

Male Wistar rats (seven weeks old) weighting 200 - $230 \mathrm{~g}$ were obtained from the National Laboratory Animal Centre, Mahidol University, Thailand. Rats were maintained in an environmentally controlled room $\left(23 \pm 2{ }^{\circ} \mathrm{C} ; 50 \pm 20 \%\right.$ humidity $)$ with a $12 \mathrm{~h}$ light/dark cycle and given ad libitum access to water and food. The experiments were conducted according to the protocols approved by the Experimental Animal Care and Use Committee of the National Laboratory Animal Centre, Mahidol University (approval no. RA2010-02). 
http://wjst.wu.ac.th

\section{Experimental diets}

Pak-wanban (Sauropus androgynus L. Merr.) leaves were purchased from three representative local markets in Bangkok and the metropolitan area. The samples were firstly washed with tap water to discard dust and then washed with deionized (DI) water (Millipore ${ }^{\mathrm{TM}}$ ). They were prepared by mean of a normal Thai household cooking technique. The samples were weighed and divided into two portions. The first portion was a raw sample and the second portion was cooked samples by stir-frying using a common household cooking method. Briefly, the samples were stir-fried with commercial cooking oil without CoQ10 and alpha-tocopherol for $1.30 \mathrm{~min}$ (samples $100 \mathrm{~g}$ per $15 \mathrm{~g}$ oil). Before and after cooking, the weight of the samples was recorded. Each sample was homogenised using a general-purpose electric blender (Philips Cucina HR 1799, Indonesia). Twenty grams of the homogenised samples were kept in an acid-washed screw-capped plastic bottle for moisture analysis. The remaining homogenised samples were weighed, freeze-dried, ground into fine powder, and then weighed. Each powder was kept in an acidwashed screw-capped plastic bottle at $-10{ }^{\circ} \mathrm{C}$ until analysis. The amount of CoQ10 from the powder of Pak-wanban leaves was calculated to $0.5 \mathrm{mg}$ and $1 \mathrm{mg}$ per kilogram body weight of the rat per day.

\section{Experiment design}

After a one-week acclimation period, the rats were randomly distributed into five groups of five rats each. The rats of Group I were designated as the control group and fed with a basal diet. The rats of Group II were fed with a basal diet mixed with raw Pak-wanban leave powder $(0.5 \mathrm{mg}$ of CoQ10 per $\mathrm{kg}$ of body weight). The rats of Group III were fed a basal diet mixed with stir-fried Pak-wanban leave powder ( $0.5 \mathrm{mg}$ of CoQ10 per kg of body weight). The rats of Group IV were fed with a basal diet mixed with stir-fried Pak-wanban leave powder ( $1 \mathrm{mg}$ of CoQ10 per $\mathrm{kg}$ of body weight). The rats of Group V were fed with a basal diet and daily gavaged $(0.5 \mathrm{~mL}$ water) with commercial CoQ10 supplement powder ( $0.5 \mathrm{mg}$ of CoQ10 per $\mathrm{kg}$ of body weight).

The food consumption was measured daily, and the body weight was measured twice a week. After 3 weeks of experimentation, the animals were euthanized by inhalation of $\mathrm{CO}_{2}$. Blood samples were collected by cardiac puncture and then centrifuged to obtain the serum, which was stored at $-20{ }^{\circ} \mathrm{C}$ until used. The livers were perfused with $10 \mathrm{~mL}$ of $0.5 \%$ ice-cold saline. Other tissues were removed and stored at $-80^{\circ} \mathrm{C}$ for further analysis.

\section{Determination of the CoQ10 level in the food}

The CoQ10 content of raw Pak-wanban, stir-fired Pak-wanban and commercial Coenzyme Q10 supplement were analyzed using the method of Kettawan et al. [15]. The CoQ10 content was determined by a HPLC method with electrochemical detection (ECD) and expressed as $\mu \mathrm{g}$ per gram of sample. All measurements were done in triplicate.

\section{Determination of the CoQ10 level in the tissues and serum samples}

The liver, heart, kidney, spleen, muscle (leg) and brain tissues, as well as the serum of the rats were analysed for the levels of reduced and total CoQ10 (sum of the oxidised and reduced CoQ10) by a HPLC method with ECD, as previously described [16]. The CoQ10 level was expressed as $\mu \mathrm{g}$ per gram of tissue.

\section{Measurement of the liver and serum alpha-tocopherol levels}

The vitamin E (alpha-tocopherol) concentration was determined by HPLC with a fluorescence detector, as previously described [17,18]. The reverse-phase HPLC solvent conditions were methanol/water $(95: 5 \mathrm{v} / \mathrm{v})$ as the eluant, at a flow rate of $2 \mathrm{~mL} / \mathrm{min}$. Fluorescence was employed with excitation at $294 \mathrm{~nm}$ and emission at $350 \mathrm{~nm}$. The stock solution of the standard vitamin was prepared in ethanol and consisted in $8.0 \mathrm{mg} / \mathrm{mL}$ vitamin $\mathrm{E}$. 
http://wjst.wu.ac.th

\section{Serum antioxidant capacities}

Oxygen radical absorbance capacity (ORAC) is a standard method for measuring the antioxidant capacities in biological samples in vitro. The ORAC assay was applied according to the method of Ou et al. [19]. The blood samples were collected by cardiac puncture and then centrifuged at 10,000 $\mathrm{g}$ for $10 \mathrm{~min}$ at $4{ }^{\circ} \mathrm{C}$ for the serum preparation. The reaction consisted of $12 \mu \mathrm{L}$ of the diluted sample and $138 \mu \mathrm{L}$ of fluorescein $(14 \mu \mathrm{M})$, which was used as a target for the free radical attack. The reaction was initiated by the addition of $50 \mu \mathrm{L} 2,2^{\prime}$-azobis (2-amidinopropane) hydrochloride AAPH $(768 \mu \mathrm{M})$. The fluorescence was monitored and recorded every one minute for two hours at $485 \mathrm{~nm}$ of excitation and $538 \mathrm{~nm}$ of emission. Trolox was used as a control standard and the results were expressed as micromoles of Trolox equivalents per millilitre.

The DPPH (1,1-diphenyl-picryhydrazyl) radical scavenging capacity of each sample was determined according to the modified method of Brand-Williams et al. [20]. DPPH radicals have an absorption maximum at $517 \mathrm{~nm}$, which disappears with reduction by an antioxidant compound. The $\mathrm{DPPH}^{*}$ solution in ethanol $(600 \mu \mathrm{M})$ was prepared daily, and $3 \mathrm{~mL}$ of this solution was mixed with $30 \mu \mathrm{L}$ of the samples or Trolox. The samples were incubated for $30 \mathrm{~min}$ at $37^{\circ} \mathrm{C}$ in a water bath, and then the decrease in absorbance from the resulting solution was monitored. The standard curve was linear between $0-20 \mu \mathrm{M}$ of Trolox (final concentration). These results were expressed as TEAC (micromoles Trolox equivalent per millilitre).

The ferric reducing antioxidant potential (FRAP) assay was determined by the modified method of Benzie and Strain [21]. This method is based on the reduction, at a low $\mathrm{pH}$, of a colourless ferric complex $\left(\mathrm{Fe}^{3+}\right.$-tripyridyltriazine), which is reduced by antioxidants to a blue-coloured ferrous complex ( $\mathrm{Fe}^{2+}$-tripyridyltriazine) in which an absorption maximum at $593 \mathrm{~nm}$ develops. In the FRAP assay, Trolox $\mathrm{Fe}^{2+}$ was used as the standard. The FRAP values were expressed as micromoles of the Trolox equivalents per millilitre. The experiment was carried out in triplicate.

\section{Measurement of the liver's lipid peroxidation induced by the $\mathrm{Fe}^{2+}$ - ascorbate}

The liver was homogenised with a phosphate-EDTA buffer $(\mathrm{pH} 7.4)$ to give a final concentration of $10 \%(\mathrm{w} / \mathrm{v})$ and centrifuged at 13,000 g for 30 minutes at $4{ }^{\circ} \mathrm{C}$. The supernatants were collected and used for the analysis. Lipid peroxidation in the liver was determined by measuring the levels of the thiobarbituric acid reactive substances (TBARS), which is the reaction of thiobarbituric acid (TBA) with malondialdehyde (MDA), an end product of lipid peroxidation. The method was carried out using $50 \mathrm{mM}$ of ascorbic acid and $5 \mathrm{mM}$ of $\mathrm{FeSO}_{4}$, as previously described [22]. The TBARS were extracted using $3 \mathrm{~mL}$ of n-butanol and were determined by the fluorometric method at $515 \mathrm{~nm}$ of excitation and $553 \mathrm{~nm}$ of emission. The 1,1,3,3-tetraethoxypropane (TEP) was used as the TBARS standard. The values of TBARS were expressed as $\mathrm{mM}$.

\section{Statistical analysis}

The results were presented as means \pm SD. The statistical Package for the Social Sciences (SPSS) version 13 software (SPSS Inc., Chicago, Illinois, USA) was used for all statistical analysis. Statistical significance was examined through one-way analysis of variance and Duncan tests. The level of significance was set at $p<0.05$ and $p<0.01$.

\section{Results and discussion}

The effect of stir-fried cooking on the level of Coenzyme Q10 in Pak-wanban leaves

The Coenzyme Q10 (CoQ10) contents of the raw and stir-fried of Pak-wanban leaves are shown in Table 1. The content of CoQ10 in raw $(48.1 \pm 1.5 \mathrm{ug} / \mathrm{g}$ wet basis $)$ and stir-fried $(45.9 \pm 1.1 \mathrm{ug} / \mathrm{g}$ wet basis) leaves of Pak-wanban were similar to the content of meat samples $(10-50 \mathrm{ug} / \mathrm{g})$, as found in previous research studies $[3,23]$. Stir-fried cooking with commercial oil without CoQ10 did not reduce the CoQ10 content of the cooked Pak-wanban compared with that of the uncooked sample whereas the study of Weber et al. [3] showed that the effect of cooking resulted in a $14-32 \%$ destruction of CoQ10 by frying, but there was no detectable destruction by boiling. 
http://wjst.wu.ac.th

Table 1 The Coenzyme Q10 contents of Pak-wanban leaves.

\begin{tabular}{llll}
\hline CoQ10 $(\boldsymbol{\mu g}$ /g sample) & Raw Pak-wanban & Stir-fried Pak-wanban & P value \\
\hline Wet Basis & $48.1 \pm 1.5$ & $45.9 \pm 1.1$ & NS \\
Dry Basis & $231.1 \pm 3.0$ & $219.6 \pm 2.3$ & NS \\
\hline
\end{tabular}

Note: Data are mean \pm SD of triplicate analysis; The Student's unpaired $t$ test was used for the statistical analysis. NS $=$ not significant $(p>0.05)$.

\section{Influence of Pak-wanban consumption on the status of Coenzyme Q10}

There were no significant intergroup differences in the food intake and final body weight (data not shown). The incorporation of Pak-wanban powder both of 0.5 and $1.0 \mathrm{mg}$ per $\mathrm{kg}$ of body weight per day did not alter either the daily food intake or body weight gain.

As shown in Table 2, Pak-wanban consumption led to an increase of the CoQ10 content in the serum and tissues of rats. The concentration of serum CoQ10 in the rats of Group IV, (1.0 mg of CoQ10 per kg body weight from stir-fried Pak-wanban), was significantly higher $(p<0.05)$ than that of the control group, Group II (0.5 mg of CoQ10 per kg body weight from raw Pak-wanban), Group III (0.5 mg of CoQ10 per kg body weight from stir-fried Pak-wanban), and Group V (0.5 mg of CoQ10 per kg body weight from commercial supplement). For Group IV that had $1.0 \mathrm{mg}$ of CoQ10 per $\mathrm{kg}$ body weight from stir-fried Pak-wanban, the spleen and liver tissues had a significantly $(p<0.05)$ higher content of CoQ10 compared to the control group. The increase of plasma and liver CoQ10 in rats fed with $1 \mathrm{mg}$ of CoQ10 per $\mathrm{kg}$ body weight from stir-fried Pak-wanban were closed to also found in rats group fed with CoQ10 supplement $(0.5 \mathrm{mg} / \mathrm{kg}$ body weight). Previous study showed that commercial CoQ10 supplementation ( $1 \mathrm{~g} / \mathrm{kg}$ diet) increased serum and liver CoQ10 [24], our results showed that dietary CoQ10 also increased serum and liver CoQ10. Furthermore, a previous study of rats administered with CoQ10 supplement by gastric intubation found that CoQ10 was absorbed into the spleen, liver and serum. The uptake of CoQ10 by the liver tissue was found to be dose dependent, $10 \mu \mathrm{mol} \mathrm{mg/100} \mathrm{g} \mathrm{of} \mathrm{body} \mathrm{weight,} \mathrm{whereas} \mathrm{the}$ uptake by the spleen could be to a large extent be accounted by the blood CoQ10 content of this organ [25]. CoQ9 is a major form of ubiquinone in the rat. We also analyzed the CoQ9 content in serum and organs, however there were not significantly changed in every group.

When comparing the rats fed with raw (Group II) and stir-fried Pak-wanban (Group III) in the same content of CoQ10 (0.5 mg of CoQ10 per kg body weight), stir-fried Pak-wanban tended to have a higher level of CoQ10 in the serum and tissues. These results were in agreement that the uptake mechanism for CoQ10 appeared to be similar to that of vitamin E, another lipid-soluble nutrient. The absorption of CoQ10 was enhanced in the presence of lipids [26].

For Group IV, $1.0 \mathrm{mg}$ of CoQ10 per kg body weight from stir-fried Pak-wanban, the distribution of tissue CoQ10 followed the order: spleen $>$ liver $>$ brain $>$ kidney $>$ heart $>$ muscle. In the control group, the distribution of tissue CoQ10 followed the order: spleen $>$ brain $>$ kidney $>$ heart $>$ liver $>$ muscle. The study of Zhang et al. [24] showed the distribution of tissue CoQ10 in rats that followed the order: brain $>$ heart $>$ kidney $>$ liver $>$ muscle. The physiological aspect of the function of CoQ10 in mammalian organisms, tissues with high-energy requirements or metabolic activity; such as, the heart, kidney, liver and muscle contained relatively high concentrations of CoQ10 [27].

In the control group, the rats fed with Pak-wanban leaves and CoQ10 supplementation, a reduced form was the major form of CoQ10 in the serum and liver tissues. The results agreed with Aberg et al. [28] and Zhang et al. [25] who found that a major portion of CoQ10 in serum and tissues was in a reduced form as the hydroquinone or ubiquinol with the exception of the brain and lungs. Data from rat studies indicate that CoQ10 is reduced to ubiquinol either during or following absorption in the intestine [26]. 
http://wjst.wu.ac.th

Table 2 Coenzyme Q10 content in the serum and tissues of rats fed with the different diets.

\begin{tabular}{|c|c|c|c|c|c|}
\hline & Group I & Group II & Group III & Group IV & Group V \\
\hline $\begin{array}{l}\text { Serum } \\
\text { CoQ10 }(\mathrm{ng} / \mathrm{mL})^{1}\end{array}$ & $85.1 \pm 4.2^{\mathrm{e}}$ & $98.3 \pm 5.4^{\mathrm{d}}$ & $114.7 \pm 7.8^{\mathrm{c}}$ & $137.6 \pm 9.2^{\mathrm{a}}$ & $125.7 \pm 10.4^{b}$ \\
\hline Reduced $(\%)^{2}$ & $90.7 \pm 1.5$ & $87.9 \pm 3.2$ & $88.2 \pm 1.7$ & $91.1 \pm 2.2$ & $89.4 \pm 1.9$ \\
\hline $\begin{array}{l}\text { Liver } \\
\text { CoQ10 }(\mu \mathrm{g} / \mathrm{g})^{1} \\
\text { Reduced }(\%)^{2}\end{array}$ & $\begin{array}{l}16.2 \pm 2.4^{\mathrm{e}} \\
65.6 \pm 4.5 \\
\end{array}$ & $\begin{array}{l}19.8 \pm 0.7^{\mathrm{d}} \\
62.1 \pm 3.2 \\
\end{array}$ & $\begin{array}{l}23.1 \pm 2.2^{\mathrm{c}} \\
66.2 \pm 2.6\end{array}$ & $\begin{array}{l}31.5 \pm 2.0^{\mathrm{a}} \\
64.8 \pm 2.1\end{array}$ & $\begin{array}{l}26.0 \pm 2.6^{\mathrm{b}} \\
63.5 \pm 3.8\end{array}$ \\
\hline $\begin{array}{l}\text { Heart } \\
\text { CoQ10 }(\mu \mathrm{g} / \mathrm{g})^{1} \\
\text { Reduced }(\%)^{2}\end{array}$ & $\begin{array}{l}19.2 \pm 1.4^{\mathrm{bc}} \\
29.2 \pm 2.8\end{array}$ & $\begin{array}{l}17.3 \pm 2.1^{\mathrm{d}} \\
28.5 \pm 1.4\end{array}$ & $\begin{array}{l}18.1 \pm 0.9^{\mathrm{cd}} \\
32.4 \pm 2.5\end{array}$ & $\begin{array}{l}21.4 \pm 2.5^{\mathrm{a}} \\
31.9 \pm 1.8 \\
\end{array}$ & $\begin{array}{l}19.8 \pm 4.3^{\mathrm{b}} \\
32.8 \pm 2.4 \\
\end{array}$ \\
\hline $\begin{array}{l}\text { Kidney } \\
\text { CoQ10 }(\mu \mathrm{g} / \mathrm{g})^{1} \\
\text { Reduced }(\%)^{2}\end{array}$ & $\begin{array}{l}22.0 \pm 1.8^{\mathrm{cd}} \\
34.1 \pm 2.4\end{array}$ & $\begin{array}{l}20.8 \pm 3.4^{\mathrm{d}} \\
36.2 \pm 1.8\end{array}$ & $\begin{array}{l}22.5 \pm 3.3^{b c} \\
33.5 \pm 0.9\end{array}$ & $\begin{array}{l}24.7 \pm 2.1^{\mathrm{a}} \\
34.7 \pm 2.9\end{array}$ & $\begin{array}{l}23.9 \pm 0.8^{\mathrm{ab}} \\
32.1 \pm 3.2\end{array}$ \\
\hline $\begin{array}{l}\text { Spleen } \\
\text { CoQ10 }(\mu \mathrm{g} / \mathrm{g})^{1} \\
\text { Reduced }(\%)^{2}\end{array}$ & $\begin{array}{l}33.5 \pm 3.8^{\mathrm{e}} \\
12.8 \pm 1.2 \\
\end{array}$ & $\begin{array}{l}35.7 \pm 1.9^{\mathrm{d}} \\
14.3 \pm 0.8\end{array}$ & $\begin{array}{l}39.1 \pm 1.3^{\mathrm{c}} \\
13.8 \pm 1.7 \\
\end{array}$ & $\begin{array}{l}51.8 \pm 4.3^{\mathrm{a}} \\
14.9 \pm 2.4 \\
\end{array}$ & $\begin{array}{l}45.1 \pm 2.4^{b} \\
14.5 \pm 0.9\end{array}$ \\
\hline $\begin{array}{l}\text { Muscle } \\
\text { CoQ10 }(\mu \mathrm{g} / \mathrm{g})^{1} \\
\text { Reduced }(\%)^{2}\end{array}$ & $\begin{array}{l}4.1 \pm 0.4^{\mathrm{ab}} \\
35.4 \pm 2.4\end{array}$ & $\begin{array}{l}4.5 \pm 0.4^{\mathrm{a}} \\
36.2 \pm 1.4\end{array}$ & $\begin{array}{l}3.9 \pm 0.7^{b} \\
33.1 \pm 2.1\end{array}$ & $\begin{array}{l}4.6 \pm 0.5^{\mathrm{a}} \\
33.2 \pm 1.5\end{array}$ & $\begin{array}{l}4.3 \pm 0.5^{\mathrm{ab}} \\
34.1 \pm 0.9\end{array}$ \\
\hline $\begin{array}{l}\text { Brain } \\
\text { CoQ10 }(\mu \mathrm{g} / \mathrm{g})^{1} \\
\text { Reduced }(\%)^{2}\end{array}$ & $\begin{array}{l}24.8 \pm 0.9^{\mathrm{a}} \\
31.4 \pm 0.7\end{array}$ & $\begin{array}{l}23.2 \pm 1.1^{\mathrm{a}} \\
29.1 \pm 1.2\end{array}$ & $\begin{array}{l}25.3 \pm 2.1^{\mathrm{a}} \\
32.3 \pm 1.5\end{array}$ & $\begin{array}{l}25.0 \pm 2.2^{\mathrm{a}} \\
31.7 \pm 0.9\end{array}$ & $\begin{array}{l}23.5 \pm 1.7^{\mathrm{a}} \\
29.5 \pm 1.7\end{array}$ \\
\hline
\end{tabular}

Note: Each value is a mean \pm SD for the five rats in each group. Group I control: basal diet, Group II: raw Pakwanban $(0.5 \mathrm{mg}$ of CoQ10/kg rat), Group III: stir-fried Pak-wanban ( $0.5 \mathrm{mg}$ of CoQ10/kg rat), Group IV: stir-fried Pak-wanban (1 mg of CoQ10/kg rat), and Group V: CoQ10 supplement powder ( $0.5 \mathrm{mg}$ of CoQ10/kg rat).

${ }^{1}$ The total CoQ10 is the sum of both the reduced and oxidised forms of CoQ10.

${ }^{2}$ Reduced $(\%)=$ Reduced CoQ10/Total CoQ10 $\times 100$.

a,b,c,d,e The means with different superscripts in each same row are significantly different $(p<0.05)$.

With regards to the reduced form of CoQ10 in the serum, the rats in Group IV, which were fed with stir-fried Pak-wanban ( $1 \mathrm{mg}$ of CoQ10 per kg body weight), were found to have about $91.1 \pm 2.2 \%$ of the total CoQ10 followed by the control group (90.7 $\pm 1.5 \%)$; Group V CoQ10 supplement $(89.4 \pm 1.9 \%)$; Group III, $0.5 \mathrm{mg}$ of CoQ10 per kg body weight from stir-fried Pak-wanban $(88.2 \pm 1.7 \%)$ and Group II, $0.5 \mathrm{mg}$ of CoQ10 per kg body weight from raw Pak-wanban $(87.9 \pm 3.2 \%)$. The results agreed with previous studies $[28,29]$ which reported that about $95 \%$ of CoQ10 in the blood was in a reduced form.

For the reduced form of CoQ10 in the liver tissue, the rats in Group III, $0.5 \mathrm{mg}$ of CoQ10 per $\mathrm{kg}$ body weight from stir-fried Pak-wanban, were found to have $66.2 \pm 2.6 \%$ of the total CoQ10, followed by the control group $(65.6 \pm 4.5 \%)$; Group IV, $1.0 \mathrm{mg}$ of CoQ10 per kg body weight from stir-fried Pakwanban $(64.8 \pm 2.1 \%)$; Group V, CoQ10 supplement $(63.5 \pm 3.8 \%)$, and Group II, $0.5 \mathrm{mg}$ of CoQ10 per $\mathrm{kg}$ body weight from raw Pak-wanban $(62.1 \pm 3.2 \%)$. However, there was no difference in the reduced form of CoQ10 in the serum and tissues among all experimental rat groups.

Influence of Pak-wanban consumption on the status of alpha-tocopherol

The consequence of the intake of Pak-wanban on the status of vitamin E was evaluated. Liver alphatocopherol concentrations were markedly increased in rats fed a high dose of CoQ10 from stir-fried Pakwanban (1 mg of CoQ10 per kg body weight; Group IV) when compared with the control group ( $p<$ 
http://wjst.wu.ac.th

0.05) (Table 3). This result conferred with a previous study by Lass et al. [30] that found mice treated orally with CoQ10 had higher CoQ10 levels in the serum, liver and kidney, and higher vitamin E levels in the mitochondria of the skeletal muscle and liver. However, Weber et al. [31] showed that the serum levels of alpha-tocopherol and ascorbic acid did not change upon CoQ10 supplementation. Vitamin E ( $\alpha$ tocopherol) is a major lipid-soluble chain-breaking antioxidant found in the serum, red cells and tissues [32]. Both vitamin E and CoQ10 possess distinct lipoprotective antioxidant properties in the biological membranes. While it is likely that vitamin E represents the initial chain-breaking antioxidant during lipid peroxidation, both fully reduced $\mathrm{CoQH}_{2}$ (ubiquinol) and semi-reduced $\mathrm{CoQH}$ (ubisemiquinone) appear to efficiently recycle the resultant vitamin E phenoxyl radical back to its biologically active reduced form [33].

Table 3 Alpha-tocopherol content in the serum and liver tissue of rats fed with the different diets.

\begin{tabular}{llllll}
\hline & $\begin{array}{c}\text { Group I } \\
\text { Control }\end{array}$ & Group II & Group III & Group IV & Group V \\
\hline Serum (ug/dL) & $6.14 \pm 0.59$ & $6.04 \pm 0.32$ & $6.56 \pm 0.27$ & $6.70 \pm 0.25$ & $6.35 \pm 0.41$ \\
Liver (ug/g) & $34.2 \pm 4.6$ & $33.1 \pm 3.7$ & $36.0 \pm 3.3$ & $43.80 \pm 3.2^{*}$ & $38.2 \pm 1.9$ \\
\hline
\end{tabular}

Note: Each value is a mean \pm SD for the 5 rats in each group. Group I control: basal diet; Group II: raw Pak-wanban (0.5 mg of CoQ10/kg rat); Group III: stir-fried Pak-wanban $(0.5 \mathrm{mg}$ of CoQ10/kg rat); Group IV: stir-fried Pak-wanban (1 mg of CoQ10/kg rat) and Group V: CoQ10 supplement powder (0.5 mg of CoQ10/kg rat).

$* P<0.05$ vs the control group.

\section{Influence of Pak-wanban consumption on the status of antioxidants}

As shown in Table 4, rats fed with $1.0 \mathrm{mg}$ of CoQ10 per $\mathrm{kg}$ body weight from stir-fried Pak-wanban (Group IV) had significantly enhanced ORAC, FRAP and DPPH levels in the serum, as well as reduced liver tissue TBARS values (Table 5) when compared to the control group $(p<0.05)$.

Table 4 The levels of ORAC, FRAP and DPPH in rats fed with the different diets.

\begin{tabular}{llllll}
\hline & Group I & Group II & Group III & Group IV & Group V \\
\hline ORAC (Unit) & $13.5 \pm 1.7$ & $16.9 \pm 1.5^{*}$ & $21.3 \pm 2.3^{* *}$ & $24.4 \pm 1.9^{* *}$ & $19.5 \pm 3.2^{*}$ \\
FRAP (Unit) & $6.1 \pm 1.4$ & $8.9 \pm 0.9^{*}$ & $10.4 \pm 2.0^{*}$ & $11.9 \pm 1.1^{* *}$ & $10.2 \pm 1.9^{*}$ \\
DPPH (Unit) & $1.9 \pm 0.4$ & $1.8 \pm 0.3$ & $2.9 \pm 0.4^{*}$ & $3.4 \pm 0.7^{*}$ & $2.2 \pm 0.5$ \\
\hline
\end{tabular}

Note: Each value is a mean \pm SD for the five rats in each diet. Group I control: basal diet; Group II: raw Pak-wanban (0.5 mg of CoQ10/kg rat); Group III: stir-fried Pak-wanban $(0.5 \mathrm{mg}$ of CoQ10/kg rat); Group IV: stir-fried Pak-wanban (1 mg of CoQ10/kg rat) and Group V: CoQ10 supplement powder $(0.5 \mathrm{mg}$ of CoQ10/kg rat). Unit: micromoles Trolox equivalent per millilitre.

* $P<0.05,{ }^{* *} p<0.01$ vs the control group. 
http://wjst.wu.ac.th

Table 5 The protective effect of Coenzyme Q10 from the different diets on the liver's lipid peroxidation induced by $\mathrm{Fe}^{2+}$-ascorbate.

\begin{tabular}{llll}
\hline \multirow{2}{*}{ Group } & \multicolumn{2}{l}{ TBARS (mM) } & \\
\cline { 2 - 4 } & 15 Min & 30 Min & $1.47 \pm 0.12$ \\
Group I & $0.84 \pm 0.11$ & $1.28 \pm 0.15$ & $1.36 \pm 0.10$ \\
Group II & $1.02 \pm 0.21$ & $1.15 \pm 0.09$ & $1.29 \pm 0.08$ \\
Group III & $0.91 \pm 0.10$ & $1.20 \pm 0.17$ & $1.18 \pm 0.12^{*}$ \\
Group IV & $0.86 \pm 0.14$ & $1.05 \pm 0.12^{*}$ & $1.37 \pm 0.13$ \\
Group V & $0.94 \pm 0.14$ & $1.18 \pm 0.10$ & \\
\hline
\end{tabular}

Note: Each value is a mean \pm SD for the five rats in each diet. Group I control: basal diet; Group II: raw Pak-wanban (0.5 mg of CoQ10/kg rat); Group III: stir-fried Pak-wanban $(0.5 \mathrm{mg}$ of CoQ10/kg rat); Group IV: stir-fried Pakwanban ( $1 \mathrm{mg}$ of CoQ10/kg rat) and Group V: CoQ10 supplement powder ( $0.5 \mathrm{mg}$ of CoQ10/kg rat).

$* P<0.05$ vs the control group.

Weber et al. [31] also found that the level of lipid peroxidation measured as the TBARS in the serum of volunteers, who were supplemented with CoQ10, was decreased, which might be ascribed to an antioxidative effect of the supplied CoQ10. Moreover, the in vitro chemical test methods using FRAP and DPPH showed that the reduced form of CoQ10 presented a higher antioxidant activity than vitamin E. The prevalence of the reduced form of CoQ10 in the biological tissues was responsible for the antioxidant action of CoQ10 in a living organism [34].

This present study did not evaluate the toxicity of Pak-wanban. The previous study indicated that the intake of fresh Pak-wanban up to $10 \mathrm{~g} / \mathrm{kg}$ body weight was not found toxicity in rats by sub-chronic toxicity test [35].

\section{Conclusions}

Stir-fried cooking did not reduce the CoQ10 content of the cooked Pak-wanban. Furthermore, this animal study showed that $\mathrm{CoQ} 10$ from Pak-wanban was absorbed by several tissues including the liver, kidney and heart. The CoQ10 from stir-fried Pak-wanban was absorbed higher than raw Pak-wanban. Cooking oil may increase the bioavailability of CoQ10 from stir-fried Pak-wanban and other vegetables. Raw and stir-fried Pak-wanban have the ability to increase serum antioxidant activities.

\section{Acknowledgements}

This work was supported by a grant from Thailand Research Fund (TRF) under grant number MRG5280245.

\section{References}

[1] CM Quinzii, SD Mauro and M Hirano. Human Coenzyme Q10 Deficiency. Neurochem. Res. 2007; 32, 723-7.

[2] C Weber, A Bysted and G Holmer. Coenzyme Q10 in the diet-daily intake and relative bioavailability. Mol. Aspects. Med. 1997; 18, S251-S254.

[3] C Weber, A Bysted and G Holmer. The coenzyme Q10 content of the average Danish diet. Int. J. Vitam. Nutr. Res. 1997; 67, 123-9.

[4] MF Beal. Coenzyme Q10 administration and its potential for treatment of neurodegenerative diseases. Biofactors 1999; 9, 261-6.

[5] A Ochiai, S Itagaki, T Kurokawa, M Kobayashi, T Hirano and K Iseki. Improvement in intestinal coenzyme Q10 absorption by food intake. Yakugaku Zasshi 2007; 127, 1251-4. 
http://wjst.wu.ac.th

[6] J Fedacko, D Pella, P Fedackova, V Vargova, FD Meester, P Durcikova and RB Singh. Coenzyme Q10 in Heart and Brain Diseases. Open Nutraceut. J. 2011; 4, 69-87.

[7] H Bunawan, SN Bunawan, SN Baharum and NM Noor. Sauropus androgynus (L.) Merr. Induced Bronchiolitis Obliterans: From Botanical Studies to Toxicology. Evid. Based Compl. Alternat. Med. 2015; 2015, 714158.

[8] S Singh, DR Singh, KM Salim, A Srivastava, LB Singh and RC Srivastava. Estimation of proximate composition, micronutrients and phytochemical compounds in traditional vegetables from Andaman and Nicobar Islands. Int. J. Food Sci. Nutr. 2011; 62, 765-73.

[9] KH Lee, AM Padzil, A Syahida, N Abdullah, SW Zuhainis, M Mazaih, MR Sulaiman, DA Israf, K Shaari and NH Lajis. Evaluation of anti-inflammatory, antioxidant and antinociceptic of six Malaysian plants. J. Med. Plants Res. 2011; 5, 5555-6.

[10] N Andarwulan, R Batari, DA Sandrasari, B Bolling and H Wijaya. Flavonoid content and antioxidant activity of vegetables from Indonesia. Food. Chem. 2010; 121, 1231-5.

[11] N Benjapak, P Swatsitang and S Tanpanich. Determination of antioxidant capacity and nutritive values of Pak-Wanban (Sauropus androgynus L. Merr.). KKU Sci. J. 2008; 36, 279-89.

[12] A Rahmat, V Kumar, LM Fong, S Endrini and HA Sani. Determination of total antioxidant activity in three types of local vegetable shoots and the cytotoxic effect of their ethanolic extracts against different cancer cell lines. Asia Pac. J. Clin. Nutr. 2004; 13, 308-11.

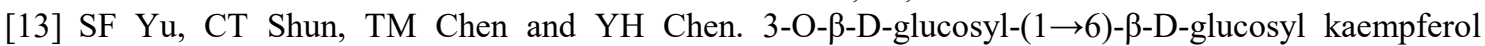
isolated from Sauropus androgynus reduces body weight gain in Wistar rats. Biol. Pharm. Bull. 2006; 29, 2510-3.

[14] M Paul and KB Anto. Antibacterial activity of Sauropus androgynus (L.) Merr. Int. J. Plant Sci. $2011 ; 6,189-92$.

[15] A Kettawan, C Kunthida, T Takahashi, T Kishi, J Chikazawa, Y Sakata and T Okamoto. The quality control assessment of commercially available coenzyme Q10-containing dietary and health supplements in Japan. J. Clin. Biochem. Nutr. 2007; 41, 124-31.

[16] T Okamoto, Y Fukunaga, Y Ida and T Kishi. Determination of reduced and total ubiquinones in biological materials by liquid chromatography with electrochemical detection. J. Chromatogr. 1988; 430, $11-9$.

[17] C Barbas, M Castro, B Bonet, M Viana and E Herrera. Simultaneous determination of vitamins A and $\mathrm{E}$ in rat tissues by high-performance liquid chromatography. J. Chromatogr. A 1997; 778, 415 20.

[18] T Ueda and O Igarash. Determination of vitamin E in biological specimens and foods by HPLCpretreatment of samples and extraction of tocopherols. J. Micronutr. Anal. 1990; 7, 79-96.

[19] B Ou, M Hampsch-Woodill and RL Prior. Development and validation of an improved oxygen radical absorbance capacity assay using fluorescein as the fluorescent probe. J. Agric. Food Chem. 2001; 49, 4619-26.

[20] W Brand-Williams, ME Cuvelier and C Berset. Use of a free radical method to evaluate antioxidant activity. Lebenson. Wiss. Technol. 1995; 28, 25-30.

[21] FF Benzie and JJ Strain. Ferric reducing/antioxidant power assay: Direct measure of total antioxidant activity of biological fluids and modified version for simultaneous measurement of total antioxidant power and ascorbic acid concentration. Meth. Enzymol. 1998; 299, 15-27.

[22] M Takei, M Hiramatsu and A Mori. Inhibitory effects of calcium antagonists on mitochondrial swelling induced by lipid peroxidation or arachidonic acid in the rat brain in vitro. Neurochem. Res. 1994; 19, 1199-206.

[23] P Ercan and S Nehir. Changes in content of coenzyme Q10 in beef muscle, beef liver and beef heart with cooking and in vitro digestion. J. Food Compos. Anal. 2011; 24, 1136-40.

[24] Y Zhang, M Turunen and EL Appelkvist. Restricted uptake of dietary coenzyme Q is in contrast to the unrestricted uptake of a-tocopherol into rat organs and cells. J. Nutr. 1996; 126, 2089-97.

[25] Y Zhang, F Aberg, EL Appelkvist, G Dallner and L Ernster. Uptake of dietary coenzyme Q supplement is limited in rats. J. Nutr. 1995; 125, 446-53. 
http://wjst.wu.ac.th

[26] HN Bhagavan and RK Chopra. Coenzyme q10: Absorption, tissue uptake, metabolism and pharmacokinetics. Free Radic. Res. 2006; 40, 445-453.

[27] L Ernster and G Dallner. Biochemical, physiological and medical aspects of ubiquinone function. Biochim. Biophys. Acta 1995; 1271, 195-204.

[28] F Aberg, EL Appelkvist, G Dallner and L Ernster. Distribution and redox state of ubiquinones in rat and human tissues. Arch. Biochem. Biophys. 1992; 295, 230-4.

[29] MV Miles, PS Horn, JA Morrison, PH Tang, T DeGrauw and AJ Pesce. Plasma coenzyme Q10 reference intervals, but not redox status, are affected by gender and race in self-reported healthy adults. Clin. Chim. Acta 2003; 332, 123-32.

[30] A Lass, MJ Forster and RS Sohal. Effects of coenzyme Q10 and alpha-tocopherol administration on their tissue levels in the mouse: elevation of mitochondrial alpha-tocopherol by coenzyme Q10. Free Radic. Biol. Med. 1999; 26, 1375-82.

[31] C Weber, TS Jakobsen, SA Mortensen, G Paulsen and G Holmer. Effect of dietary coenzyme Q10 as an antioxidant in human plasma. Mol. Aspects. Med. 1994; 15, s97-s102.

[32] GW Burton and MG Traber. Vitamin E: Antioxidant activity, biokinetics, and bioavailability. Annu. Rev. Nutr. 1990; 10, 357-82.

[33] A Mellors and AL Tappel. The inhibition of mitochondrial peroxidation by ubiquinone and ubiquinol. J. Biol. Chem. 1966; 241, 4353-6.

[34] R Cervellati and E Grecoa. In vitro antioxidant activity of ubiquinone and ubiquinol, compared to vitamin E. Helv. Chim. Acta 2016; 99, 41-5.

[35] X Xi-kun, Y Guo-guang and Z Jing. Evaluatiion of toxicity and safty of Sauropus androgynus[J]. Chin. J. Public Health 2011; 27, 1553-5. 